
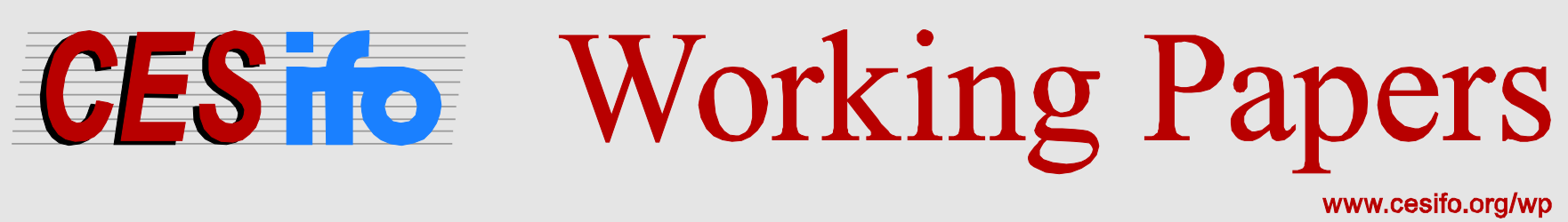

\title{
Manipulating Fiscal Forecasts: Evidence from the German States
}

\author{
Björn Kauder \\ Niklas Potrafke \\ Christoph Schinke
}
CESIFO WORKING PAPER NO. 6310
CATEgory 2: Public CHOICE
JANUARY 2017
An electronic version of the paper may be downloaded
- from the SSRN website:
- from the RePEc website:
- from the CESifo website:
WwW.SSRN.com
www.RePEc.org
www.CESifo-group.org/wp

\section{CESifo}




\title{
Manipulating Fiscal Forecasts: Evidence from the German States
}

\begin{abstract}
We examine whether German state governments manipulated fiscal forecasts before elections. Our data set includes three fiscal measures over the period 1980-2014. The results do not show that electoral motives influenced fiscal forecasts in West German states. By contrast, East German state governments underestimated spending in pre-election years (compared to other years) by about 0.20 percent of GDP, tax revenues by about 0.36 percent of GDP, and net lending by 0.30 percent of GDP. Predicting low levels of spending and tax revenues, East German state governments thus underestimated the size of government in pre-election years.
\end{abstract}

JEL-Codes: H680, E320, E620.

Keywords: fiscal forecasts, electoral cycles, East and West Germany.

Björn Kauder

Ifo Institute - Leibniz Institute for

Economic Research at the University of Munich

Poschingerstrasse 5

Germany - 81679 Munich

kauder@ifo.de
Niklas Potrafke*

Ifo Institute - Leibniz Institute for

Economic Research

at the University of Munich

Poschingerstrasse 5

Germany-81679 Munich

potrafke@ifo.de

Christoph Schinke

Ifo Institute - Leibniz Institute for

Economic Research

at the University of Munich

Poschingerstrasse 5

Germany - 81679 Munich

schinke@ifo.de

*corresponding author

10 January 2017

This paper has been accepted for publication in FinanzArchiv/Public Finance Analysis. We would like to thank Christian Breuer, Robert Lehmann, Felix Rösel, and Christian Thater for their helpful comments. Dominik Hecker, Lion Henrich, Julia Richenhagen, and Julia Tubes provided excellent research assistance. Financial support by the Fritz Thyssen Foundation is gratefully acknowledged. 


\section{Introduction}

Governments prepare forecasts on tax revenues, spending and deficits. Most realizations do, of course, not meet the forecasted values. An important question is whether fiscal forecast errors simply result from unforeseeable circumstances, or whether forecast errors are tantamount to manipulation by governments. There are political incentives towards manipulation. In times of an approaching election, for example, governments may use fiscal forecasts to boost re-election prospects (the political business cycle theory describes that politicians use expansionary policies before elections). ${ }^{1}$ By manipulating tax revenue, spending, or deficit forecasts, parties that champion tax cuts or increased spending wish to convey the impression that individual policies are fundable. Voters endorsing such reforms may then be inclined to reconsider their vote. Against the background of the political business cycle theories, the hypothesis to be tested is clear-cut: governments are over-optimistic and sugarcoat fiscal forecasts before elections by expecting too high tax revenues and too low spending and deficits.

Scholars examine whether electoral motives and government ideology influence fiscal forecasts. We discuss related studies in section 2 and for now focus on Germany. Fiscal forecasts at the German federal level were biased towards over-optimism in the period 19682003: deficit forecasts were lower before elections; deficit, tax, and spending forecasts were lower under right-wing governments (Heinemann, 2006). For short-term tax revenue forecasts in the period 1971-2013, the results of Buettner and Kauder (2015) are not indicative of a bias, electoral cycles or an influence of government ideology; the government influenced the revenue forecasts, however, by providing the underlying GDP forecast and revenue estimates of tax law changes. Medium-term tax revenue forecasts between 1968 and 2012 were biased

\footnotetext{
${ }^{1}$ On how electoral motives influence fiscal policy, see, for example, Berger and Woitek (1997), de Haan and Klomp (2013), Efthyvoulou (2012), Katsimi and Sarantidis (2012), Klomp and de Haan (2013), Lane (2003), Seitz (2000), and Shi and Svensson (2006). See Debrun et al. (2009) and Wyplosz (2008) on fiscal councils. On election-motivated policies in the German states see, for example, Tepe and Vanhuysse (2009), Mechtel and Potrafke (2013), and Kauder et al. (2016).
} 
upwards, in particular after the German reunification (Breuer, 2015). For the West German states in the period 1992-2002, the results of Bischoff and Gohout (2010) do not give rise to the conclusion that electoral motives and government ideology influenced tax projections. Tax projections increased, however, the more voters disliked incumbent parties.

Our contribution is twofold. We examine whether politicians manipulated spending, tax revenue, and net lending forecasts at the German state level. We also investigate differences in strategic manipulation of fiscal variables between East and West German state governments. The results show that in pre-election years (compared to other years) East German state governments underestimated spending by about 0.20 percent of GDP, tax revenues by 0.36 percent of GDP, and net lending by 0.30 percent of GDP. Predicting low levels of spending and tax revenues, East German state governments thus underestimated the size of government. The results do, by contrast, not show that electoral motives influenced fiscal forecasts in West German states.

\section{Related literature}

Experts investigate the quality of forecasts in terms of precision and accuracy, as measured, for example, by the standard deviation of the forecast error. In OECD countries, the timing of forecasts, uncertainty about GDP growth rates, and independence of forecasting institutions from government were shown to influence accuracy of revenue forecasts (Buettner and Kauder, 2010). In US states, forecast accuracy increased with independent forecasting agencies and decreased when there was a dominant political party (Deschamps, 2004; Bretschneider et al., 1989). Revenue forecast accuracy also increased when states employed politically appointed and merit-selected forecasters (Krause et al., 2006).

Testing the precision and accuracy of forecasts refers to the forecasting techniques. To test whether governments manipulate forecasts before elections, experts examine the 
rationality of forecasts in terms of unbiasedness and efficiency, as measured, for example, by the relative forecast error (see Keane and Runkle, 1989 and 1990; Nordhaus, 1987; Holden and Peel, 1990). Do individual factors give rise to overly optimistic or overly pessimistic (and hence biased) forecasts? Do forecasters incorporate all relevant information available at the time of the forecast preparation (efficiency)?

Many empirical studies investigated the rationality of fiscal forecasts in cross-country analyses or in individual countries. ${ }^{2}$ In member states of the European Union, budget balance forecasts were over-optimistic before elections (Brück and Stephan, 2006; Merola and Pérez, 2013; Pina and Venes, 2011). The results of von Hagen (2010), however, do not corroborate election-year effects. Budget forecasts were also too optimistic during boom periods and when the budget deficit was high (Frankel, 2011; Frankel and Schreger, 2013). Jonung and Larch (2006) portray the nexus between growth forecasts and budget balances and suggest that having independent forecasts may avoid political biases (see also Beetsma et al., 2009). In OECD countries, electoral motives do not appear to have influenced fiscal balance revisions (Cimadomo, 2012; Jong-A-Pin et al., 2012). Left-wing governments, however, produced more optimistic revenue forecasts than right-wing governments (Jochimsen and Lehmann, in press).

In the United States (federal level), evidence suggests that revenue forecasts of the Office of Management and Budget (OMB) and the Congressional Budget Office (CBO) were not biased, spending and thus deficits were underestimated, and forecast revisions were serially correlated; biases were larger under Republican administrations (Auerbach, 1999; Blackley and DeBoer, 1993; Campbell and Ghysels, 1995; Plesko, 1988). In US states, revenue forecasts were shown to be unbiased but inefficient (Mocan and Azad, 1995). Revenue forecasts for election years, however, were shown to be overly optimistic (Boylan,

\footnotetext{
${ }^{2}$ See Kyobe and Danninger (2005) and Schroeder and Wasylenko (1989) for revenue forecasting in low-income countries. Leal et al. (2008) discuss "lessons and challenges" from fiscal forecasting in the European Union.
} 
2008). Conservatives were over-optimistic in forecasting sales tax revenues in years without tax increases (Bretschneider and Gorr, 1992). The results of Cassidy et al. (1989) do not suggest that government ideology influenced forecast errors. In three US states, forecasts were shown to be downward biased (Feenberg et al., 1989).

In Belgian municipalities, two-party governments were more optimistic in forecasting tax revenues than single-party governments (Goeminne et al., 2008). In Swiss cantons, revenue forecasts were more pessimistic under left-wing finance ministers than under rightwing finance ministers (Chatagny, 2015), and pessimistic revenue forecasts were shown to reduce spending and thus fiscal deficits (Chatagny and Soguel, 2012). ${ }^{3}$ Also in the United Kingdom, political factors influenced revenue forecasts (Paleologou, 2005).

The mixed evidence on forecasting performance advanced by the individual studies corroborates that exploring political determinants of fiscal forecast errors is a worthwhile endeavor. Whether German state governments manipulated fiscal forecasts remains as an undetermined empirical question.

\section{Institutional backdrop}

\subsection{Budget rules}

The German constitution describes in Article 109 that the states are autonomous and independent from the federal level in setting up their budgets. In 2009, the so-called debt brake was introduced, describing that state budgets should in principle be balanced without borrowing as of 2020. Exceptions can be made for business fluctuations, natural disasters, and other cases of emergency, if specific rules describe how credits are repaid. State governments can decide on whether they want to comply with the debt brake earlier and how a balanced budget is to be reached (see, for example, Potrafke et al., 2016). It is unclear, however,

\footnotetext{
${ }^{3}$ See Chatagny and Siliverstovs (2015) on the rationality of tax revenue forecasts under asymmetric loss functions.
} 
whether there will be sanctions if a state fails to consolidate the budget until 2020 (Fuest and Thöne, 2013). To be sure, the federal debt brake does not make any prescriptions for the states’ fiscal policies until 2019. Since 2009, twelve states have introduced debt brakes at the state level.

Most states' constitutions describe that borrowing has to be warranted by a law. Borrowing must moreover not exceed spending for investment; exceptions are only possible to maintain the "overall economic equilibrium”. Many states however disregarded the law and borrowing exceeded investment.

\subsection{Projections of fiscal figures}

The Federal Minister of Finance Franz Josef Strauß (Christian Social Union - CSU) and his successor Alex Möller (Social Democratic Party - SPD) introduced medium-term planning in 1968 at both the federal and the state level. Medium-term plans are set up in the budgeting process and include fiscal forecasts for the current and the following four years (see also Lübke, 2008). Forecasted figures include, among others, spending, tax revenues, and net lending. Even though states also receive transfers from the federal level and from the other states via the financial equalization scheme, tax revenues are the most important source of revenue. Tax revenue forecasts are prepared by the independent tax revenue forecast group (Arbeitskreis Steuerschätzungen) on the federal level. The subcommittee on regionalization calculates how much tax revenues may accrue to the individual states. The state governments adjust these figures for reasons such as the timing of the budgetary process, economic development of the state or tax reforms.

For some years in individual states, medium-term plans are not available, because in some cases state governments passed a budget for two years, and thus published medium-term plans only every other year. We focus on the most important figures referring to year $\mathrm{t}$ and $t+1$ because governments' budget plans are based on the forecasts for the years $t$ and $t+1$. 


\subsection{State elections}

Elections in the German states take place every five years. The only exceptions are Hamburg and Bremen, where elections take place every four years. In the past, even more states held elections every four years. Parliaments may also call early elections. Out of 109 elections in our sample, 11 were early elections. In most states, voters cast two votes in a personalized proportional representation system. The first vote determines which candidate is to obtain the direct mandate in one of the electoral districts with a relative majority. With the second vote, voters select an individual party. The parties obtain a number of the seats in parliament that corresponds to the party's second vote share. Candidates voted into the parliament with the first vote (direct mandate) obtain their seats first. Candidates from party lists obtain the remaining seats.

\section{Empirical analysis}

\subsection{Descriptive statistics}

We use the fiscal forecasts from 1980-2014 for West German states and from 1996-2014 for East German states as published by the ministries of finance in the individual states. We exclude fiscal forecasts from the East German states before 1996 and for Berlin between 1990 and 1995 because of the German reunification. Table 1a shows descriptive statistics for all states. A positive (negative) forecast error indicates that the expected value of a fiscal variable was overstated (understated) compared to the ex-post realization. Average forecast errors for total spending and tax revenues for the same year and the next year were less than 0.07 percent of GDP. Average forecast errors for net lending were larger: net lending for the same year and the next year was underestimated by 0.22 percent of GDP and 0.15 percent of GDP on average. The root mean squared error of forecasts for the same year is 0.38 percent of GDP for total spending, 0.40 for tax revenues, and 0.52 for net lending. Root mean squared errors 
increase as the forecast horizon increases. Tables $1 \mathrm{~b}$ and $1 \mathrm{c}$ show descriptive statistics separately for East German states and West German states.

Figure 1 shows the forecast errors for three fiscal measures in year $t$ and $t+1$. We distinguish between the last fiscal forecast before a state election (in light gray) and other forecasts (in dark gray). We call the last fiscal forecast before a state election "pre-election forecast” henceforth, as opposed to “other forecasts”. Whiskers describe 95 percent confidence intervals. Total spending was always underestimated, except in forecasts for year t in other years. Forecasts of total spending before elections and in other years appear to differ. Tax revenue forecast errors were quite small and similar before elections and in other years. Net lending was always underestimated, i.e. deficits were lower than predicted. The difference of forecast errors before elections and in other years hardly ever attains statistical significance.

The results may differ between East and West German states because institutions have developed differently between 1949 and 1990, and institutional differences may influence fiscal forecasts after the reunification. Figure 2 shows the results separately for East and West German states. In many cases, the difference between pre-election forecast errors and other forecast errors was larger in East German states than in West German states. ${ }^{4}$ In East German states, forecast errors were mostly lower before elections than in other years. Forecast errors of total spending in year $\mathrm{t}(\mathrm{t}+1)$ were on average 0.11 percent of GDP $(0.23$ percent of GDP) lower before elections than in other years. The difference of total spending forecast errors before elections and in other years for the next year in the East attains statistical significance at the 10 percent level. Forecast errors of tax revenues in year $t(t+1)$ were on average 0.01 percent of GDP (0.02 percent of GDP) lower (higher) before elections than in other years. Forecast errors of net lending in year $t(t+1)$ were on average 0.01 percent of GDP $(0.02$ percent of GDP) higher (lower) before elections than in other years.

\footnotetext{
${ }^{4}$ Eastern firms also predict their productivity less accurately than Western firms (Triebs and Tumlinson, 2013).
} 
Figures 3a to 3c show how the forecast errors for the three fiscal measures in year $t$ and $t+1$ evolved over time. Because uncertainty differs, forecast errors for year $t$ are in absolute values smaller than forecast errors for year $t+1$. Forecast errors in absolute values are larger in East German states, in particular for tax revenues and net lending.

\subsection{Empirical strategy}

The basic empirical model has the following form:

$$
\text { Forecast error }_{i j k t}=\beta_{j k} \text { Pre-election }_{i t}+\Sigma_{l} \delta_{j k l} X_{i l t}+\varepsilon_{j k} \text { Forecast error }_{i j k t-1}+\eta_{i j k}+\tau_{j k t}+u_{i j k t}
$$

$$
\text { with } i=1, \ldots, 16 ; j=1, \ldots, 3 ; k=0,1 ; l=1, \ldots, 3 ; t=1980, \ldots, 2014
$$

where Forecast error ${ }_{i j k t}$ describes the difference between forecast and realized value for forecast type $j$ (total spending, tax revenues, and net lending) relative to realized GDP with

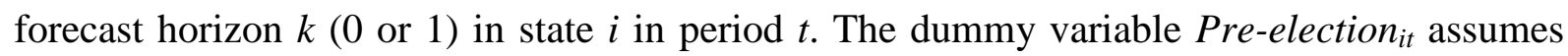
the value 1 when the forecast was the last forecast issued before a regular state election (predetermined elections are exogenous explanatory variables). $\Sigma_{l} X_{\text {ilt }}$ contains three control variables. We include the ideological orientation of the respective government. ${ }^{5}$ We include the unemployment rate to account for different incentives to manipulate forecasts in economically good and bad times. ${ }^{6}$ We also include the variable whose forecast error we consider as a share of realized GDP from one period ago to control for mean reversion. Forecast error $_{i j k t-1}$ describes the lagged dependent variable to control for autocorrelation of forecast errors. $\eta_{i}$ describes a fixed state effect, $\tau_{t}$ is a fixed time effect, and $u_{i t}$ is the error term.

\footnotetext{
${ }^{5}$ We distinguish between left-wing and right-wing governments on a left-right scale by using the variable Left. The variable Left takes on the value 1 in periods when a left-wing government was in office (SPD without a coalition partner, or SPD in a coalition with the Greens, the left-wing party Die Linke or the Free Democratic Party (FDP)), 0.5 when a center government (coalition of the Christian Democratic Union (CDU) with the SPD or the Greens, or with the Greens and the FDP), and 0 when a right-wing government was in office (CDU/CSU without a coalition partner or in a coalition with the FDP). On ideology-induced policy-making in the German states see, for example, Oberndorfer and Steiner (2007) and Potrafke (2011).

${ }^{6}$ Inferences do not change when we use the GDP growth rate instead of the unemployment rate.
} 
We estimate fixed-effects models with standard errors robust to heteroskedasticity (Huber/White/sandwich standard errors - Huber, 1967; White, 1980). Including the lagged dependent variable gives rise to Nickell bias (Nickell, 1981), which is however small (1/T).

\subsection{Regression results}

Table 2 shows the results for all states. Column (1) shows the coefficient estimates for the forecast of total spending for the same year (the pre-election year), and column (2) shows the results for the next year (the election year). The number of observations decreases as the forecast horizon increases. The coefficient of the election variable and the coefficient of the government ideology variable do not turn out to be statistically significant. The coefficient of the lagged forecast error is significant in columns (1) and (2). The numerical meaning of the coefficient in column (1) is that when the lagged forecast error increases by 1 percent of GDP, the current forecast error increases by 0.32 percent of GDP. The coefficient of the lagged unemployment rate lacks statistical significance. Columns (3) to (6) show the results for tax revenues and net lending. The coefficient of the election variable does not turn out to be statistically significant in any specification. The coefficient of the government ideology variable is statistically significant in column (5). The numerical meaning of the coefficient is that under left-wing governments, net lending forecast errors decrease by 0.6 percentage points of GDP compared to right-wing governments. The coefficient of the lagged realization of net lending is statistically significant in column (5).

We estimate our basic empirical model separately for the East and West German states. Table 3 shows the results for East German states (excluding Berlin). ${ }^{7}$ The coefficient of the pre-election variable is negative and statistically significant for total spending in year $\mathrm{t}$ and year $\mathrm{t}+1$ (columns 1 and 2), tax revenues in year $\mathrm{t}$ (column 3), and net lending in year $\mathrm{t}$

\footnotetext{
${ }^{7}$ We cannot distinguish the East German from the West German part of Berlin. We therefore include Berlin only in the regressions for all 16 states.
} 
(column 5). The numerical meaning of the coefficient in column (1) is that in pre-election years, total spending is underestimated by 0.20 percent of GDP (compared to other years). Tax revenues are underestimated by 0.36 percent of GDP in pre-election years (column 3); net lending is underestimated by 0.30 percent of GDP in pre-election years (column 5). Note that the forecast errors for government spending and tax revenues do not add up to the forecast error for net lending. The discrepancy arises from forecast errors for revenues from sources other than taxes, such as transfers from the federal level, revenues from state-owned companies, capital receipts, fees, and fines. Yet, taxes are the most important source of revenues in all states. The coefficient of state government ideology is statistically significant for total spending in year $t$ and year $t+1$ and for tax revenues in year $t$. The numerical meaning of the coefficient in column (1) is that under left-wing governments, total spending is overestimated by 0.66 percent of GDP more than under right-wing governments.

Table 4 shows the results for West German states. The coefficient of the election variable lacks statistical significance in all specifications.

We also used forecast errors for total spending, tax revenues, and net lending in years $t+2, t+3$, and $t+4$ as dependent variables. The coefficient of the election variable does not turn out to be statistically significant in any specification, except for net lending at the $t+3$ years forecast horizon which in pre-election years (compared to other years) is underestimated by 0.47 percent of GDP in East German states (results not shown).

\subsection{Robustness tests}

We submitted all of our results to several robustness tests. In our baseline model, we included fixed time effects. We tested whether inferences change when we do not include fixed time effects but the deviation between the GDP forecast of the Federal government as underlying the official revenue forecasts and actual GDP to measure economic uncertainty (at the 
national level). Inferences regarding the election variable do not change. When we do not include a lagged dependent variable in the regressions, inferences do not change either.

We have included other control variables. Inferences regarding the election variable do not change when we include variables measuring the level of education of voters (percent of population above 15 years with university degree), ${ }^{8}$ the state unemployment rate relative to the German average, or a variable that assumes the value one when a state has a fiscal rule (debt brake) included in the constitution or in the state budget code.

The results may depend on including irregular elections. The only irregular election in East Germany was in Berlin in 2001. Berlin is not included in the regressions reported in table 3. There were 10 irregular elections in West Germany over the period 1980-2014. Inferences for West Germany do not change when we include the irregular elections.

Realizations of fiscal variables after changes in government may be less predictable than realizations after elections that did not give rise to changes in government. There were 43 regular elections that were followed by a change in government ideology and 61 regular elections that were not followed by a change in government ideology. Replicating the results for the 16 states (table 2) confirms that before elections that induced changes in government ideology (compared to other years), total spending for the next year was underestimated by 0.20 percent of GDP, and tax revenues for the same year were underestimated by 0.07 percent of GDP (both coefficients are statistically significant at the 5 percent level). Replicating the results for West Germany (table 4) confirms that before elections that induced changes in government ideology (compared to other years), tax revenues for the same year were underestimated by 0.05 percent of GDP (the coefficient is statistically significant at the 5 percent level). Because of the limited number of observations we cannot investigate subsamples in East Germany.

\footnotetext{
${ }^{8}$ Data on education levels in individual states is only available over the period 2005-2014.
} 
We run placebo tests and replace the pre-election variable with dummy variables for other years. When we use a dummy variable for election years and re-estimate table 3 , the coefficient of the election-year variable is negative and statistically significant in columns (2) and (5). When we use a dummy variable measuring a two-year distance to the next election and re-estimate table 3, the coefficient of the dummy variable always lacks statistical significance. When we use a dummy variable measuring a three year distance to the next election and re-estimate table 3, the coefficient of the dummy variable is positive and statistically significant in columns (2) and (3).

We re-estimated our regression models for the West German states for the period 1996-2014, i.e. the same period that we examine for the East German states. Inferences regarding the coefficients of the election variable do not change. In particular, the results still do not show a bias in forecasts before elections.

We re-estimated our regression models for the period 1992-2002 in the West German states to compare our results more closely with Bischoff and Gohout (2010). Our results also do not show (a) that tax revenue forecasts were biased in pre-election years and (b) that state government ideology influenced tax revenue forecast errors for the next year.

Forecast errors may have increased during the financial and debt crisis. When we exclude the crisis years 2008 and 2009, we find that in the full sample (replicating table 2) spending for the same year was underestimated by 0.08 percent of GDP in pre-election years (compared to other years). The coefficient is significant at the 10 percent level. Replicating table 3 (East Germany), inferences do not change, except for column (1), where the election variable lacks statistical significance. Replicating table 4, the results still do not show that fiscal forecasts were biased in West Germany in pre-election years.

When we exclude individual years, one at a time, we find that the main findings for the East German states are robust. The election variable does not turn out to be statistically significant in column (1) when we exclude the years 1998, 2001, 2005, 2007, 2008, 2010 or 
2013 and in column (1) and (3) when we exclude the year 2003. The coefficients of the election variable, however, remain negative throughout all specifications.

The city states Bremen and Hamburg may differ from other West German states. We re-estimated the regressions for all states and for the West German states, excluding Bremen and Hamburg. Inferences regarding the election variable do not change.

Jackknife tests in which we exclude an individual state, one at a time, corroborate that the main findings generalize to most states. In the sample including the East German states, the election variable lacks statistical significance in column (1) when we exclude Brandenburg or Saxony, in columns (1) and (5) when we exclude Mecklenburg-Western Pomerania, and in columns (1), (2), and (5) when we exclude Saxony-Anhalt. When we exclude Thuringia, the election variable does not turn out to be statistically significant in columns (1), (3), and (5). While standard errors increase when we exclude individual states, the coefficients of the election variable remain negative throughout all specifications.

\section{Conclusion}

Our findings do not indicate that electoral motives influenced fiscal forecasts in West German states, a result that corroborates previous findings of Bischoff and Gohout (2010). By contrast, in pre-election years (compared to other years) East German state governments underestimated spending by about 0.20 percent of GDP, tax revenues by 0.36 percent of GDP, and net lending by 0.30 percent of GDP. East German state governments were thus overoptimistic regarding spending and net lending, and over-pessimistic regarding tax revenues. Our prediction that governments sugarcoat all three fiscal forecasts by being over-optimistic before elections cannot be corroborated. Predicting low levels of spending and tax revenues, East German state governments rather underestimated the size of government and overestimated their ability to decrease the size of government. 
Why is it that East German state governments underestimated the size of government and West German state governments did not? ${ }^{9}$ It is well known that the communist experience in Eastern Germany between 1949 and 1990 influenced social norms and attitudes towards government differently than the market-based system in the West (Alesina and Fuchs-Schündeln, 2007; Brosig-Koch et al., 2011). Many studies describe differences between East and West Germans regarding cooperation and solidarity behavior (Ockenfels and Weimann, 1999; Brosig-Koch et al., 2011), individual preferences for social policies and redistribution (Corneo, 2004; Alesina and Fuchs-Schündeln, 2007), and inequality of wages, income, and consumption (Fuchs-Schündeln et al., 2010). We can however not test whether differences in social norms and attitudes towards government give rise to our results. We propose an alternative explanation. At the time of the reunification, Chancellor Helmut Kohl promised "blossoming landscapes" in East Germany, describing a quick convergence in economic prosperity. The size of government in East German states is however still larger than in West German states, some convergence since the 1990’s notwithstanding (figure 4). We conjecture that East German state governments wanted to pretend convergence to the West German states by using forecasts in pre-election years as a low-cost signaling device. East German politicians may well believe that promising a size of government similar to Western states is valued by voters, the stronger preferences for redistribution in East Germany notwithstanding (note that redistribution is a federal task and that the largest share in state government spending is staff spending). Whether voters reward such promises remains however as an open question for further research.

\footnotetext{
${ }^{9}$ Previous studies have shown that ideology-induced policies differed in East and West German states (Tepe and Vanhuysse, 2014; Kauder and Potrafke, 2013; Potrafke, 2013).
} 


\section{References}

Alesina, A., and Fuchs-Schündeln, N. (2007), Good-Bye Lenin (or Not?): The Effect of Communism on People’s Preferences, American Economic Review 97, 1507-1528.

Auerbach, A.J. (1999), On the Performance and Use of Government Revenue Forecasts, National Tax Journal 52, 767-782.

Beetsma, R., Giuliodori, M., and Wierts, P. (2009), Planning to Cheat: EU Fiscal Policy in Real Time, Economic Policy 24, 753-804.

Berger, H., and Woitek, U. (1997), Searching for Political Business Cycles in Germany, Public Choice 91, 179-197.

Bischoff, I., and Gohout, W. (2010), The Political Economy of Tax Projections, International Tax and Public Finance 17, 133-150.

Blackley, P.R., and DeBoer, L. (1993), Bias in OMB's Economic Forecasts and Budget Proposals, Public Choice 76, 215-232.

Boylan, R.T. (2008), Political Distortions in State Forecasts, Public Choice 136, 411-427.

Bretschneider, S.I., and Gorr, W.L. (1992), Economic, Organizational, and Political Influences on Biases in Forecasting State Sales Tax Receipts, International Journal of Forecasting 7, 457-466.

Bretschneider, S.I., Gorr, W.L., Grizzle, G., and Klay, E. (1989), Political and Organizational Influences on the Accuracy of Forecasting State Government Revenues, International Journal of Forecasting 5, 307-319.

Breuer, C. (2015), On the Rationality of Medium-Term Tax Revenue Forecasts: Evidence from Germany, Jahrbücher für Nationalökonomie und Statistik 235, 22-40.

Brosig-Koch, J., Helbach, C., Ockenfels, A., and Weimann, J. (2011), Still Different after All These Years: Solidarity Behavior in East and West Germany, Journal of Public Economics 95, 1373-1376.

Brück, T., and Stephan, A. (2006), Do Eurozone Countries Cheat with their Budget Deficit Forecasts? Kyklos 59, 3-15.

Buettner, T., and Kauder, B. (2010), Revenue Forecasting Practices: Differences across Countries and Consequences for Forecasting Performance, Fiscal Studies 31, 313-340.

Buettner, T., and Kauder, B. (2015), Political Biases despite External Expert Participation? An Empirical Analysis of Tax Revenue Forecasts in Germany, Public Choice 164, 287-307.

Campbell, B., and Ghysels, E. (1995), Federal Budget Projections: A Nonparametric Assessment of Bias and Efficiency, Review of Economics and Statistics 77, 17-31.

Cassidy, G., Kamlet, M.S., and Nagin, D.S. (1989), An Empirical Examination of Bias in Revenue Forecasts by State Governments, International Journal of Forecasting 5, 321331.

Chatagny, F. (2015), Incentive Effects of Fiscal Rules on the Finance Minister's Behavior: Evidence from Revenue Projections in Swiss Cantons, European Journal of Political Economy 39, 184-200. 
Chatagny, F., and Siliverstovs, B. (2015), Evaluating Rationality of Level and Growth Rate Forecasts of Direct Tax Revenues under Flexible Loss Function: Evidence from Swiss Cantons, Economics Letters 134, 65-68.

Chatagny, F., and Soguel, N.C. (2012), The Effect of Tax Revenue Budgeting Errors on Fiscal Balance: Evidence from the Swiss cantons, International Tax and Public Finance 19, 319-337.

Cimadomo, J. (2012), Fiscal Policy in Real Time, Scandinavian Journal of Economics 114, 440-465.

Corneo, G. (2004), Wieso Umverteilung? Einsichten aus ökonometrischen Umfrageanalysen, in: Genser, B. (Ed.), Finanzpolitik und Umverteilung, Duncker \& Humblot, Berlin, 5588.

Debrun, X., Hauner, D., and Kumar, M.S. (2009), Independent Fiscal Agencies, Journal of Economic Surveys 23, 44-81.

De Haan, J., and Klomp, J. (2013), Conditional Political Budget Cycles: A Review of Recent Evidence, Public Choice 157, 387-410.

Deschamps, E. (2004), The Impact of Institutional Change on Forecast Accuracy: A Case Study of Budget Forecasting in Washington State, International Journal of Forecasting 20, 647-657.

Efthyvoulou, G. (2012), Political Budget Cycles in the European Union and the Impact of Political Pressures, Public Choice 153, 295-327.

Feenberg, D.R., Gentry, W., Gilroy, D., and Rosen, H.S. (1989), Testing the Rationality of State Revenue Forecasts, Review of Economics and Statistics 71, 300-308.

Frankel, J. (2011), Over-optimism in Forecasts by Official Budget Agencies and its Implications, Oxford Review of Economic Policy 27, 536-562.

Frankel, J., and Schreger, J. (2013), Over-optimistic Official Forecasts and Fiscal Rules in the Eurozone, Review of World Economics 149, 247-272.

Fuchs-Schündeln, N., Krueger, D., and Sommer, M. (2010), Inequality Trends for Germany in the Last Two Decades: A Tale of Two Countries, Review of Economic Dynamics 13, 103-132.

Fuest, C., and Thöne, M. (2013), Durchsetzung der Schuldenbremse in den Bundesländern, FiFo Köln.

Goeminne, S., Geys, B., and Smolders, C. (2008), Political Fragmentation and Projected Tax Revenues: Evidence from Flemish Municipalities, International Tax and Public Finance 15, 297-315.

Heinemann, F. (2006), Planning or Propaganda? An Evaluation of Germany’s Medium-term Budgetary Planning, FinanzArchiv/Public Finance Analysis 62, 551-578.

Holden, K., and Peel, D.A. (1990), On Testing for Unbiasedness and Efficiency of Forecasts, Manchester School 58, 120-127.

Huber, P.J. (1967), The Behavior of Maximum Likelihood Estimates under Nonstandard Conditions, Proceedings of the Fifth Berkeley Symposium on Mathematical Statistics and Probability, 221-233. 
Jochimsen, B., and Lehmann, R. (in press), On the Political Economy of National Tax Revenue Forecasts: Evidence from OECD Countries, Public Choice.

Jong-A-Pin, R., Sturm, J.E., and de Haan, J. (2012), Using Real-Time Data to Test for Political Budget Cycles, CESifo Working Paper No. 3939.

Jonung, L., and Larch, M. (2006), Improving Fiscal Policy in the EU: The Case for Independent Forecasts, Economic Policy 21, 491-534.

Katsimi, M., and Sarantidis, V. (2012), Do Elections affect the Composition of Fiscal Policy in Developed Established Democracies? Public Choice 151, 325-362.

Kauder, B., Krause, M., and Potrafke, N. (2016), Electoral Cycles in MPs' Salaries: Evidence from the German States, CESifo Working Paper No. 6028.

Kauder, B., and Potrafke, N. (2013), Government Ideology and Tuition Fee Policy: Evidence from the German States, CESifo Economic Studies 59, 628-649.

Keane, M.P., and Runkle, D.E. (1989), Are Economic Forecasts Rational? Quarterly Review of the Federal Reserve Bank of Minneapolis 13, 26-33.

Keane, M.P., and Runkle, D.E. (1990), Testing the Rationality of Price Forecasts: New Evidence from Panel Data, American Economic Review 80, 714-735.

Klomp, J., and de Haan, J. (2013), Political Budget Cycles and Election Outcomes, Public Choice 157, 245-267.

Krause, G.A., Lewis, D.E., and Douglas, J.W. (2006), Political Appointments, Civil Service Systems, and Bureaucratic Competence: Organizational Balancing and Executive Branch Revenue Forecasts in the American States, American Journal of Political Science 50, 770-787.

Kyobe, A., and Danninger, S. (2005), Revenue Forecasting - How is it done? Results from a Survey of Low-Income Countries, IMF Working Paper No. 05/24.

Lane, P.R. (2003), The Cyclical Behaviour of Fiscal Policy: Evidence from the OECD, Journal of Public Economics 87, 2661-2675.

Leal, T., Pérez, J.J., Tujula, M., and Vidal, J.-P. (2008), Fiscal Forecasting: Lessons from the Literature and Challenges, Fiscal Studies 29, 347-386.

Lübke, A. (2008), Medium-term Financial Planning in the Federal Republic of Germany, Presupuesto y Gasto Público 51, 133-144.

Mechtel, M., and Potrafke, N. (2013), Electoral Cycles in Active Labour Market Policies, Public Choice 156, 181-194.

Merola, R., and Pérez, J.J. (2013), Fiscal Forecast Errors: Governments versus Independent Agencies? European Journal of Political Economy 32, 285-299.

Mocan, H.N., and Azad, S. (1995), Accuracy and Rationality of State General Fund Revenue Forecasts: Evidence from Panel Data, International Journal of Forecasting 11, 417427.

Nickell, S. (1981), Biases in Dynamic Models with Fixed Effects, Econometrica 49, 14171426.

Nordhaus, W.D. (1987), Forecasting Efficiency: Concepts and Applications, Review of Economics and Statistics 69, 667-674. 
Oberndorfer, U., and Steiner, V. (2007), Generationen- oder Parteienkonflikt? Eine empirische Analyse der deutschen Hochschulausgaben, Perspektiven der Wirtschaftspolitik 8, 165-183.

Ockenfels, A., and Weimann, J. (1999), Types and Patterns: An Experimental East-WestGerman Comparison of Cooperation and Solidarity, Journal of Public Economics 71, 275-287.

Paleologou, S.M. (2005), Political Manoeuvrings as Sources of Measurement Errors in Forecasts, Journal of Forecasting 24, 311-324.

Pina, Á.M., and Venes, N.M. (2011), The Political Economy of EDP Fiscal Forecasts: An Empirical Assessment, European Journal of Political Economy 27, 534-546.

Plesko, G.A. (1988), The Accuracy of Government Forecasts and Budget Projections, National Tax Journal 41, 483-501.

Potrafke, N. (2011), Public Expenditures on Education and Cultural Affairs in the West German States: Does Government Ideology Influence the Budget Composition? German Economic Review 12, 124-145.

Potrafke, N. (2013), Government Ideology and Economic Freedom across the German States, Regional Studies 47, 433-449.

Potrafke, N., Riem, M., and Schinke, C. (2016), Debt Brakes in the German States: Governments‘ Rhetoric and Actions, German Economic Review 17, 253-275.

Schroeder, L., and Wasylenko, M. (1989), Public Sector Forecasting in the Third World, International Journal of Forecasting 5, 333-345.

Seitz, H. (2000), Fiscal Policy, Deficits and Politics of Subnational Governments: The Case of the German Laender, Public Choice 102, 183-218.

Shi, M., and Svensson, J. (2006), Political Budget Cycles: Do they Differ across Countries and why? Journal of Public Economics 90, 1367-1389.

Tepe, M., and Vanhuysse, P. (2009), Educational Business Cycles - The Political Economy of Teacher Hiring across German States, 1992-2004, Public Choice 139, 61-82.

Tepe, M., and Vanhuysse, P. (2014), A Vote at the Opera? The Political Economy of Public Theatres and Orchestras in the German States, European Journal of Political Economy 36, 254-273.

Triebs, T., and Tumlinson, J. (2013), Learning Capitalism the Hard Way - Evidence from Germany’s Reunification, NBER Working Paper No. 19209.

Von Hagen, J. (2010), Sticking to Fiscal Plans: The Role of Institutions, Public Choice 144, 487-503.

White, H. (1980), A Heteroskedasticity-Consistent Covariance Matrix Estimator and a Direct Test for Heteroskedasticity, Econometrica 48, 817-838.

Wyplosz, C. (2008), Fiscal Policy Councils: Unlovable or just Unloved? Swedish Economic Policy Review 15, 173-192. 


\section{Figure 1}

Forecast errors in pre-election years and other years
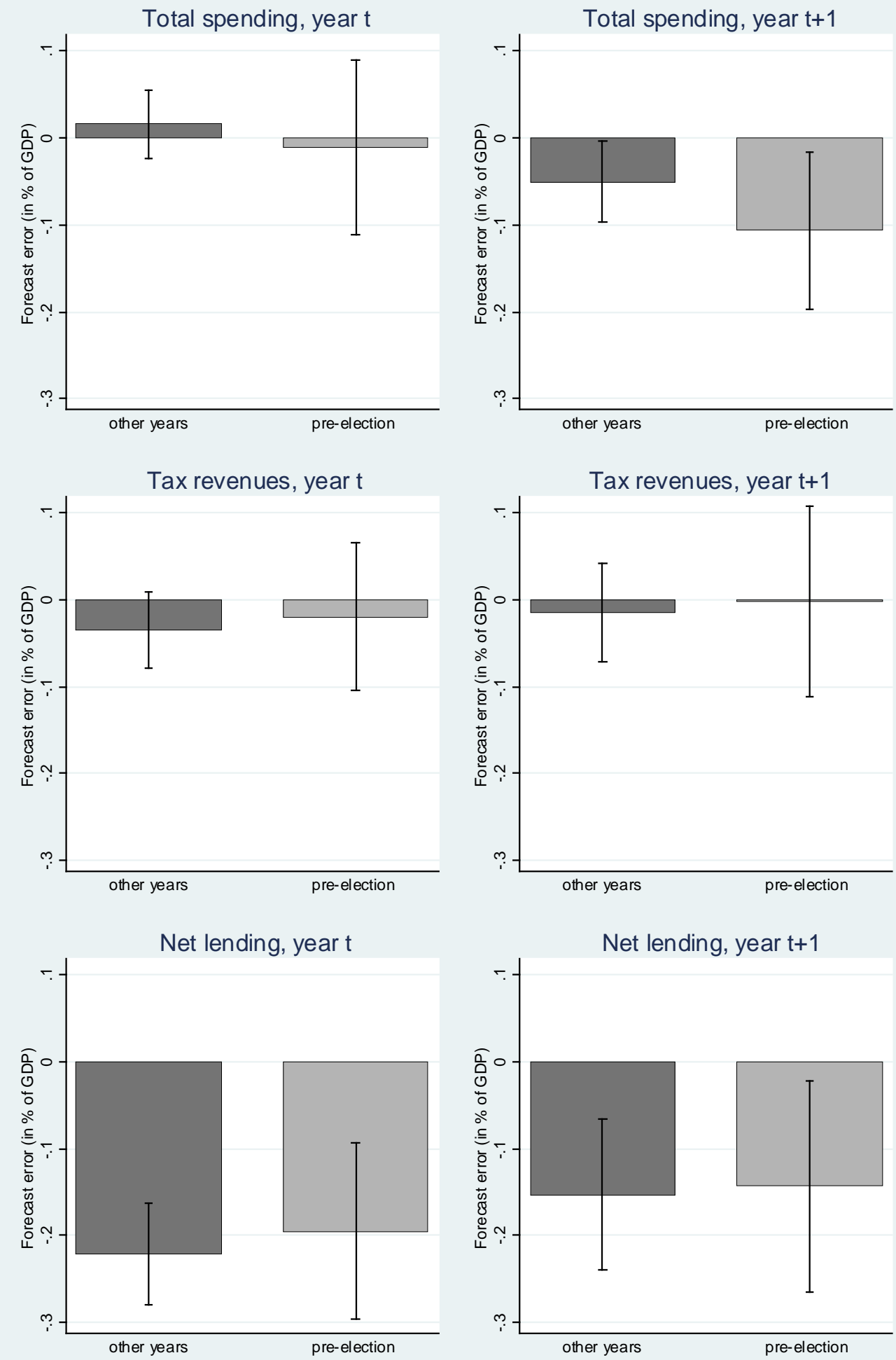

Note: The differences between pre-election and other years do not turn out to be statistically significant. Whiskers describe 95 percent confidence intervals. 


\section{Figure 2}

Forecast errors by region in pre-election years and other years
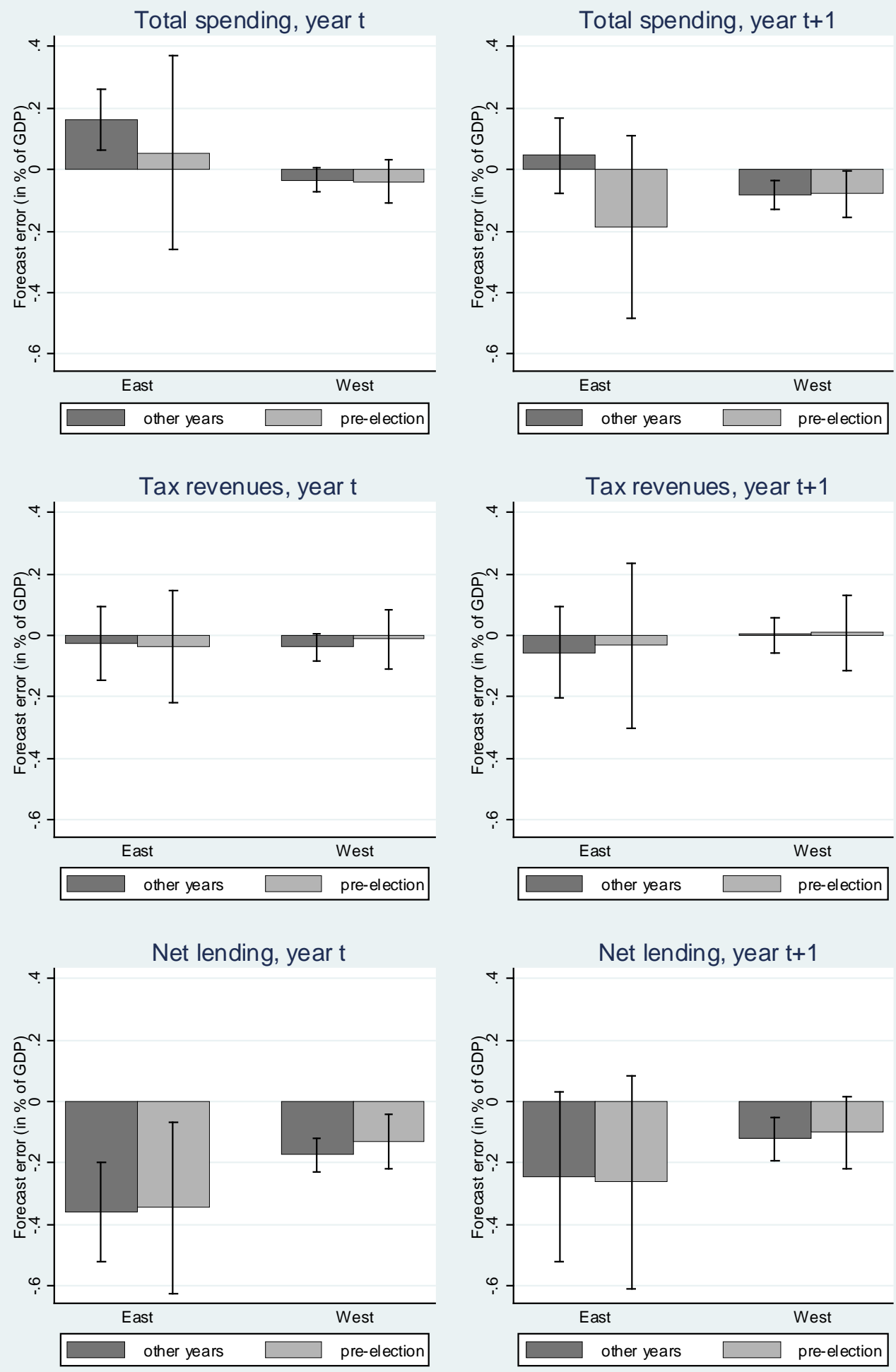

Note: The difference between pre-election and other years is statistically significant at the 10 percent level for total spending in year $\mathrm{t}+1$ in East German states. Whiskers describe 95 percent confidence intervals. 


\section{Figure 3a}

Total spending forecast errors, 1980-2014

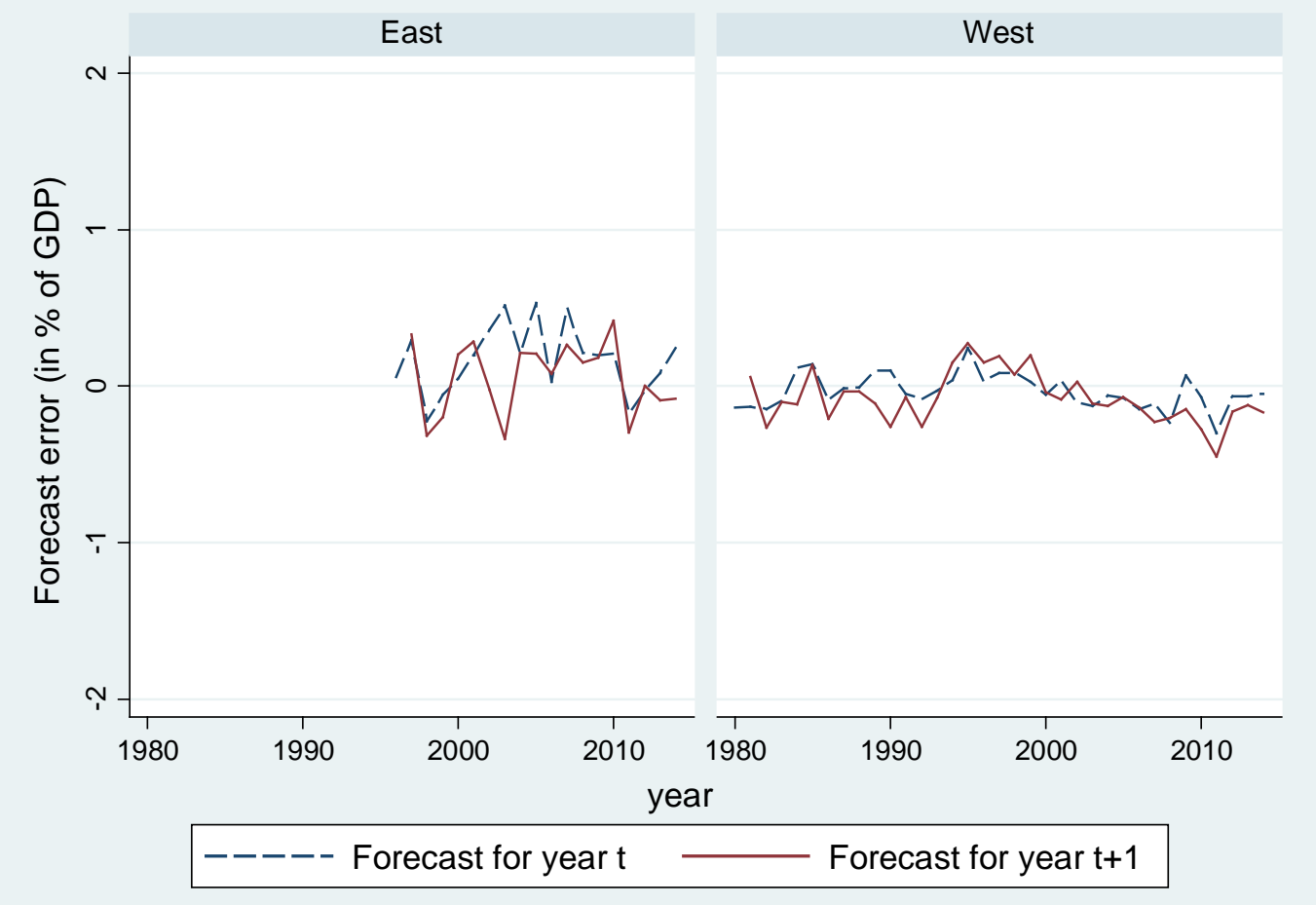

\section{Figure 3b}

Tax revenue forecast errors, 1980-2014

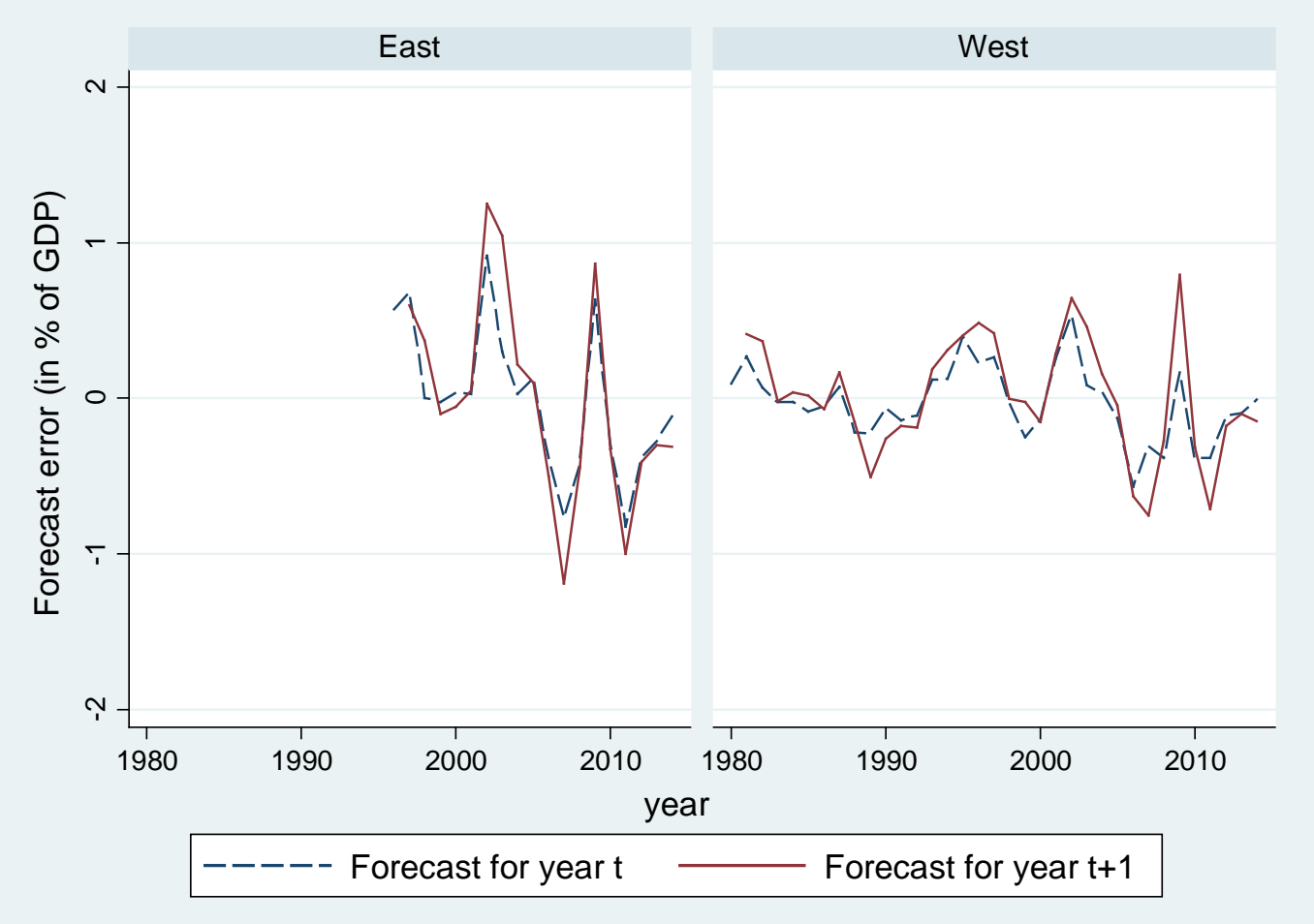




\section{Figure 3c}

Net lending forecast errors, 1980-2014

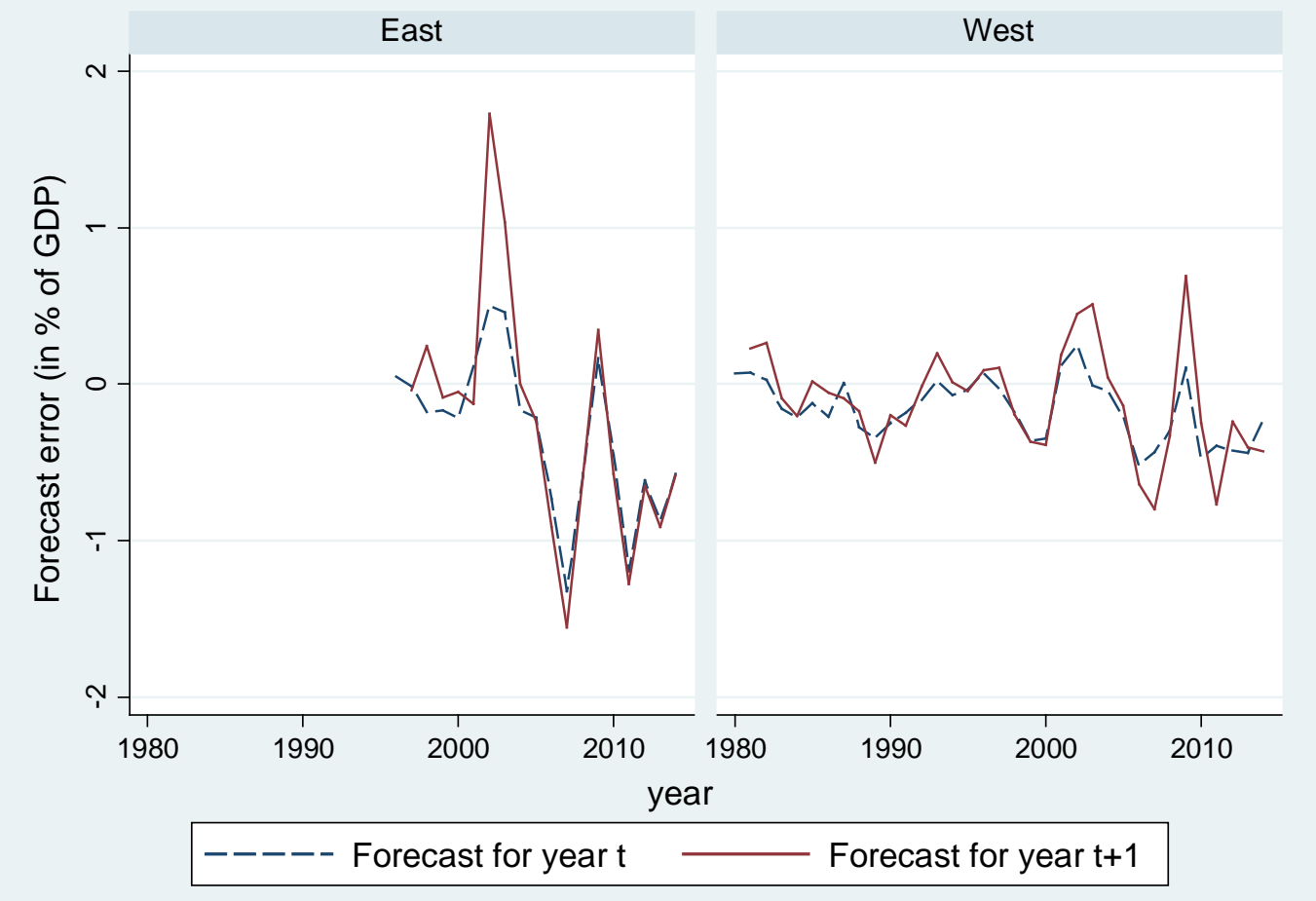

\section{Figure 4}

Total spending by state, 1980-2014

(i) East Germany

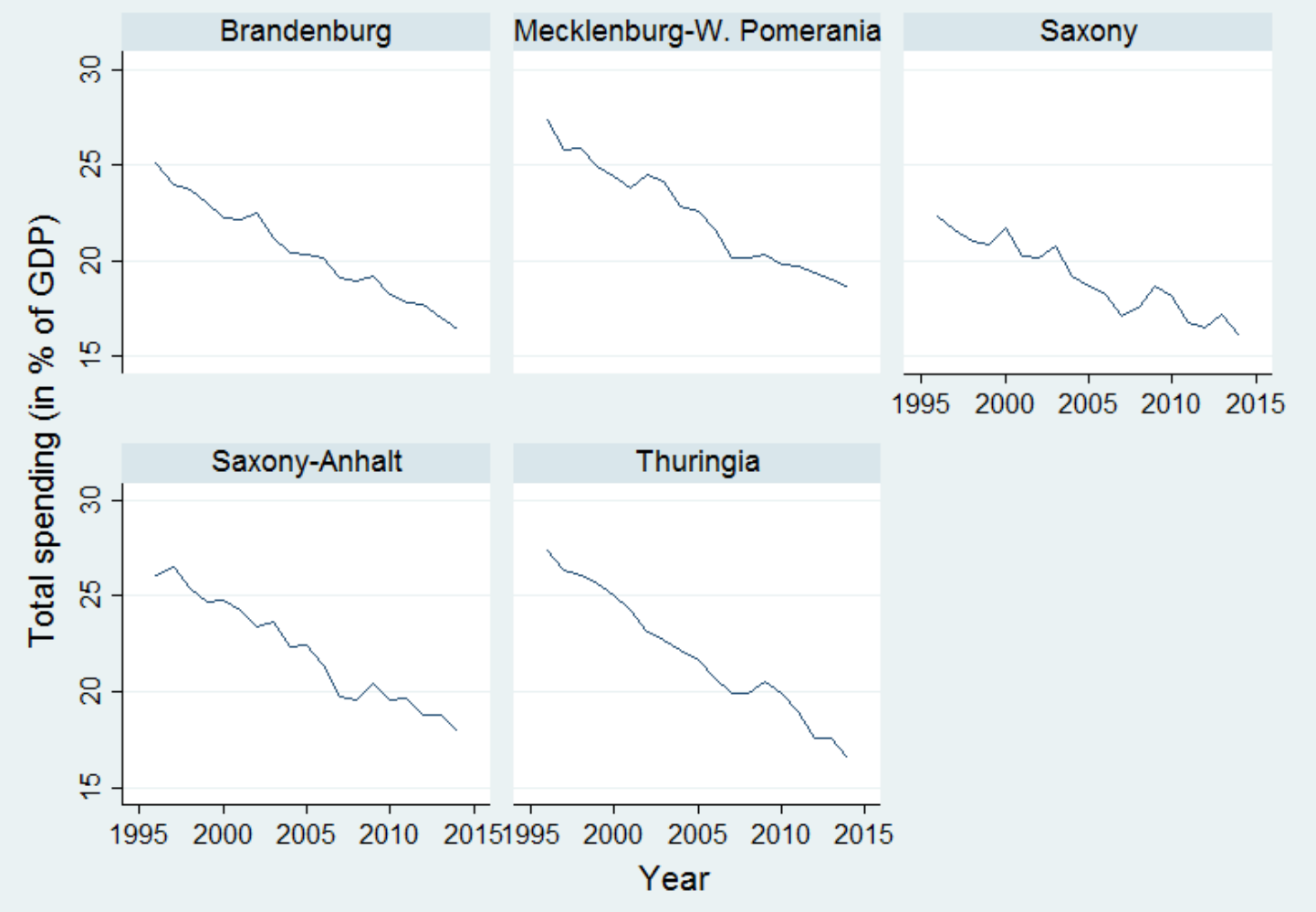


(ii) West Germany

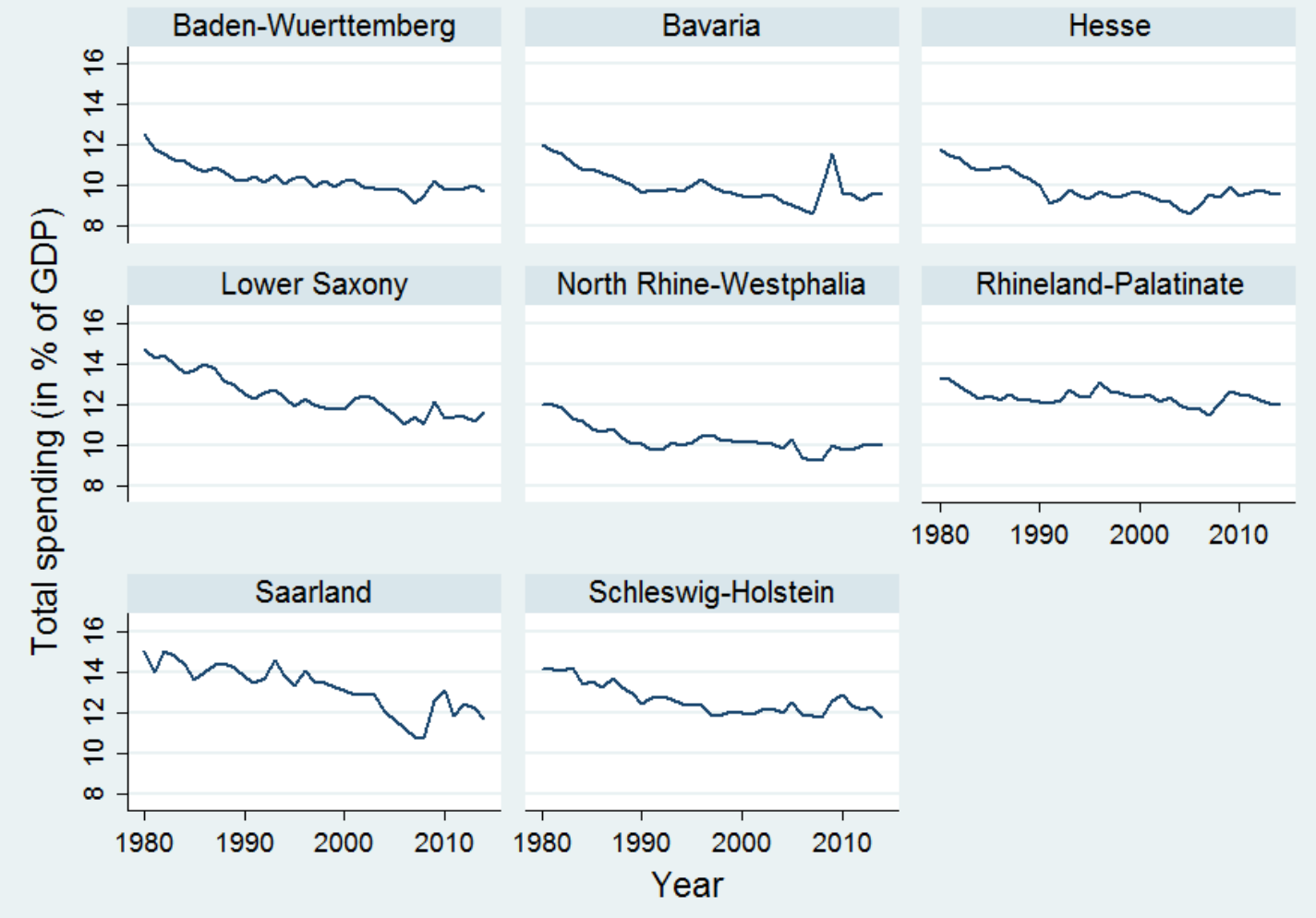

(iii) City states

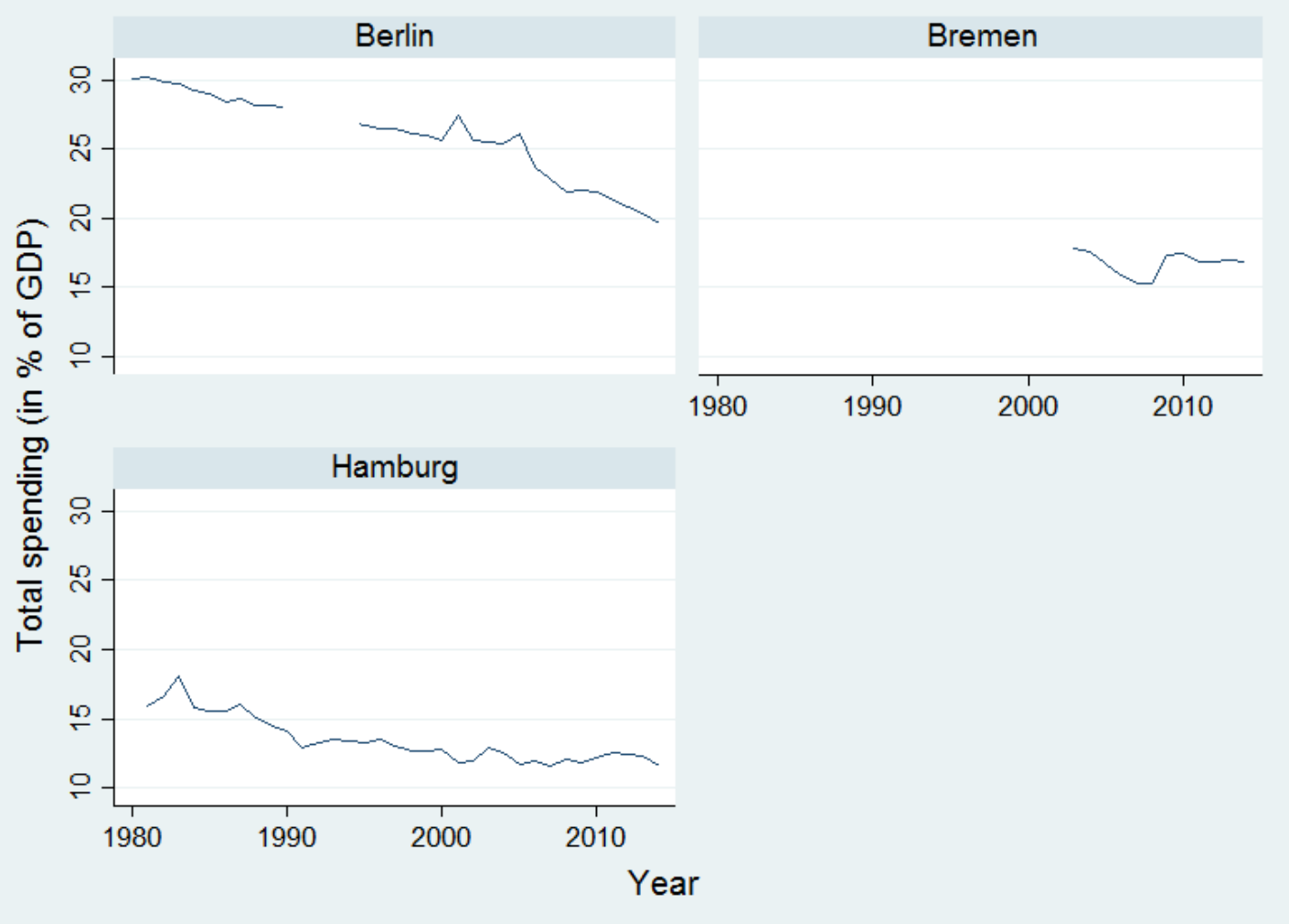


Table 1a

Descriptive statistics for all states

\begin{tabular}{|c|c|c|c|c|c|}
\hline Forecast errors (in percent of ex-post state GDP) & Obs. & ME & RMSE & Min. & Max. \\
\hline Total spending, year t & 398 & 0.011 & 0.376 & -1.916 & 1.601 \\
\hline Total spending, year $\mathrm{t}+1$ & 389 & -0.062 & 0.415 & -2.597 & 1.230 \\
\hline Total spending, year $\mathrm{t}+2$ & 374 & -0.124 & 0.516 & -2.728 & 1.380 \\
\hline Total spending, year $\mathrm{t}+3$ & 358 & -0.148 & 0.674 & -2.602 & 2.566 \\
\hline Total spending, year $\mathrm{t}+4$ & 343 & -0.135 & 0.820 & -2.690 & 2.271 \\
\hline Tax revenues, year t & 405 & -0.032 & 0.398 & -1.549 & 1.217 \\
\hline Tax revenues, year $t+1$ & 390 & -0.012 & 0.508 & -1.549 & 1.387 \\
\hline Tax revenues, year $t+2$ & 375 & 0.111 & 0.728 & -1.732 & 1.866 \\
\hline Tax revenues, year $t+3$ & 359 & 0.268 & 0.867 & -1.960 & 2.656 \\
\hline Tax revenues, year $t+4$ & 344 & 0.443 & 0.965 & -1.764 & 2.314 \\
\hline Net lending, year t & 399 & -0.216 & 0.517 & -2.407 & 1.510 \\
\hline Net lending, year $t+1$ & 390 & -0.151 & 0.733 & -2.358 & 6.281 \\
\hline Net lending, year $t+2$ & 375 & -0.096 & 0.908 & -3.609 & 6.227 \\
\hline Net lending, year $t+3$ & 359 & 0.012 & 0.910 & -3.646 & 3.900 \\
\hline Net lending, year $t+4$ & 344 & 0.114 & 0.886 & -3.766 & 3.675 \\
\hline Ex-post realizations (in percent of state GDP) & Obs. & Mean & Std. Dev. & Min. & Max. \\
\hline Total spending & 450 & 14.685 & 5.284 & 8.571 & 30.239 \\
\hline Tax revenues & 450 & 8.505 & 1.258 & 6.363 & 11.821 \\
\hline Net lending & 450 & -1.013 & 1.130 & -6.692 & 2.156 \\
\hline Unemployment rate & 474 & 10.873 & 4.466 & 2.300 & 22.100 \\
\hline GDP growth rate (nominal) & 474 & 3.168 & 2.637 & -10.000 & 10.900 \\
\hline State government ideology (left) & 474 & 0.525 & 0.453 & 0.000 & 1.000 \\
\hline Last forecast before election & 474 & 0.207 & 0.405 & 0.000 & 1.000 \\
\hline Last forecast before election that induced regime change & 474 & 0.084 & 0.278 & 0.000 & 1.000 \\
\hline Last forecast before election that did not induce regime change & 474 & 0.122 & 0.328 & 0.000 & 1.000 \\
\hline Education level & 144 & 13.285 & 3.452 & 8.096 & 25.876 \\
\hline Unemployment rate relative to state average & 474 & 0.986 & 0.325 & 0.438 & 2.216 \\
\hline Fiscal rule & 474 & 0.074 & 0.262 & 0.000 & 1.000 \\
\hline
\end{tabular}

Note: ME = Mean Error; RMSE $=$ Root Mean Squared Error. 
Table 1b

Descriptive statistics for East German states

\begin{tabular}{|c|c|c|c|c|c|}
\hline Forecast errors (in percent of ex-post state GDP) & Obs. & ME & RMSE & Min. & Max. \\
\hline Total spending, year t & 104 & 0.139 & 0.520 & -1.916 & 1.601 \\
\hline Total spending, year $\mathrm{t}+1$ & 98 & -0.002 & 0.562 & -2.597 & 1.230 \\
\hline Total spending, year $\mathrm{t}+2$ & 92 & -0.181 & 0.638 & -2.728 & 1.380 \\
\hline Total spending, year $\mathrm{t}+3$ & 86 & -0.243 & 0.830 & -2.602 & 2.566 \\
\hline Total spending, year $\mathrm{t}+4$ & 79 & -0.220 & 1.006 & -2.690 & 2.271 \\
\hline Tax revenues, year $\mathrm{t}$ & 106 & -0.029 & 0.520 & -1.549 & 1.217 \\
\hline Tax revenues, year $t+1$ & 100 & -0.050 & 0.648 & -1.549 & 1.387 \\
\hline Tax revenues, year $\mathrm{t}+2$ & 94 & 0.092 & 0.939 & -1.732 & 1.866 \\
\hline Tax revenues, year $\mathrm{t}+3$ & 88 & 0.260 & 1.147 & -1.960 & 2.079 \\
\hline Tax revenues, year $\mathrm{t}+4$ & 81 & 0.514 & 1.296 & -1.764 & 2.314 \\
\hline Net lending, year t & 105 & -0.357 & 0.720 & -2.407 & 1.380 \\
\hline Net lending, year t + 1 & 99 & -0.248 & 1.143 & -2.358 & 6.281 \\
\hline Net lending, year t + 2 & 93 & -0.187 & 1.453 & -3.609 & 6.227 \\
\hline Net lending, year $t+3$ & 87 & -0.010 & 1.444 & -3.646 & 3.900 \\
\hline Net lending, year $\mathrm{t}+4$ & 80 & 0.084 & 1.424 & -3.766 & 3.675 \\
\hline Ex-post realizations (in percent of state GDP) & Obs. & Mean & Std. Dev. & Min. & Max. \\
\hline Total spending & 124 & 22.255 & 3.537 & 16.095 & 30.239 \\
\hline Tax revenues & 124 & 10.000 & 1.036 & 7.058 & 11.608 \\
\hline Net lending & 124 & -1.120 & 1.648 & -6.692 & 2.156 \\
\hline Unemployment rate & 124 & 16.088 & 4.024 & 4.300 & 22.100 \\
\hline GDP growth rate (nominal) & 124 & 2.346 & 2.108 & -4.400 & 8.200 \\
\hline State government ideology (left) & 124 & 0.504 & 0.380 & 0.000 & 1.000 \\
\hline Last forecast before election & 124 & 0.218 & 0.414 & 0.000 & 1.000 \\
\hline Last forecast before election that induced regime change & 124 & 0.137 & 0.345 & 0.000 & 1.000 \\
\hline Last forecast before election that did not induce regime change & 124 & 0.081 & 0.273 & 0.000 & 1.000 \\
\hline Education level & 54 & 13.380 & 4.381 & 8.653 & 25.876 \\
\hline Unemployment rate relative to state average & 124 & 1.345 & 0.164 & 0.963 & 1.671 \\
\hline Fiscal rule & 124 & 0.113 & 0.318 & 0.000 & 1.000 \\
\hline
\end{tabular}

Note: ME = Mean Error; RMSE $=$ Root Mean Squared Error. 
Table 1c

Descriptive statistics for West German states

\begin{tabular}{|c|c|c|c|c|c|}
\hline Forecast errors (in percent of ex-post state GDP) & Obs. & ME & RMSE & Min. & Max. \\
\hline Total spending, year $\mathrm{t}$ & 294 & -0.035 & 0.298 & -1.596 & 1.511 \\
\hline Total spending, year $t+1$ & 291 & -0.082 & 0.351 & -1.734 & 0.888 \\
\hline Total spending, year $\mathrm{t}+2$ & 282 & -0.105 & 0.469 & -2.065 & 1.262 \\
\hline Total spending, year $\mathrm{t}+3$ & 272 & -0.117 & 0.615 & -2.582 & 1.397 \\
\hline Total spending, year $t+4$ & 264 & -0.109 & 0.756 & -2.646 & 1.524 \\
\hline Tax revenues, year t & 299 & -0.033 & 0.346 & -1.330 & 1.077 \\
\hline Tax revenues, year $\mathrm{t}+1$ & 290 & 0.001 & 0.450 & -1.330 & 1.264 \\
\hline Tax revenues, year $\mathrm{t}+2$ & 281 & 0.117 & 0.644 & -1.619 & 1.814 \\
\hline Tax revenues, year $\mathrm{t}+3$ & 271 & 0.271 & 0.756 & -1.678 & 2.656 \\
\hline Tax revenues, year $\mathrm{t}+4$ & 263 & 0.421 & 0.839 & -1.641 & 2.299 \\
\hline Net lending, year $\mathrm{t}$ & 294 & -0.165 & 0.412 & -2.106 & 1.510 \\
\hline Net lending, year $t+1$ & 291 & -0.118 & 0.524 & -2.325 & 1.777 \\
\hline Net lending, year $\mathrm{t}+2$ & 282 & -0.066 & 0.635 & -2.883 & 1.962 \\
\hline Net lending, year $t+3$ & 272 & 0.019 & 0.657 & -2.626 & 2.628 \\
\hline Net lending, year $t+4$ & 264 & 0.123 & 0.645 & -2.366 & 2.488 \\
\hline Ex-post realizations (in percent of state GDP) & Obs. & Mean & Std. Dev. & Min. & Max. \\
\hline Total spending & 326 & 11.805 & 1.911 & 8.571 & 18.032 \\
\hline Tax revenues & 326 & 7.936 & 0.777 & 6.363 & 11.821 \\
\hline Net lending & 326 & -0.973 & 0.855 & -4.784 & 1.008 \\
\hline Unemployment rate & 350 & 9.025 & 2.869 & 2.300 & 18.300 \\
\hline GDP growth rate (nominal) & 350 & 3.460 & 2.745 & -10.000 & 10.900 \\
\hline State government ideology (left) & 350 & 0.533 & 0.477 & 0.000 & 1.000 \\
\hline Last forecast before election & 350 & 0.203 & 0.403 & 0.000 & 1.000 \\
\hline Last forecast before election that induced regime change & 350 & 0.066 & 0.248 & 0.000 & 1.000 \\
\hline Last forecast before election that did not induce regime change & 350 & 0.137 & 0.344 & 0.000 & 1.000 \\
\hline Education level & 90 & 13.227 & 2.776 & 8.096 & 24.118 \\
\hline Unemployment rate relative to state average & 350 & 0.858 & 0.268 & 0.438 & 2.216 \\
\hline Fiscal rule & 350 & 0.060 & 0.238 & 0.000 & 1.000 \\
\hline
\end{tabular}

Note: ME = Mean Error; RMSE $=$ Root Mean Squared Error. 
Table 2

Fixed-effects regressions with standard errors robust to heteroskedasticity (Huber/White/sandwich standard errors) - all states

\begin{tabular}{|c|c|c|c|c|c|c|}
\hline & $\begin{array}{c}\text { (1) } \\
\text { Total } \\
\text { spending } \\
\text { forecast } \\
\text { error, } \\
\text { year t }\end{array}$ & $\begin{array}{c}(2) \\
\text { Total } \\
\text { spending } \\
\text { forecast } \\
\text { error, } \\
\text { year } \mathrm{t}+1\end{array}$ & $\begin{array}{c}\text { (3) } \\
\text { Tax revenue } \\
\text { forecast } \\
\text { error, } \\
\text { year t }\end{array}$ & $\begin{array}{c}(4) \\
\text { Tax revenue } \\
\text { forecast } \\
\text { error, } \\
\text { year } t+1\end{array}$ & $\begin{array}{c}\text { (5) } \\
\text { Net lending } \\
\text { forecast } \\
\text { error, } \\
\text { year t }\end{array}$ & $\begin{array}{c}\text { (6) } \\
\text { Net lending } \\
\text { forecast } \\
\text { error, } \\
\text { year } \mathrm{t}+1\end{array}$ \\
\hline $\begin{array}{l}\text { Pre-election } \\
\text { forecast }\end{array}$ & $\begin{array}{l}-0.083 \\
(0.050)\end{array}$ & $\begin{array}{l}-0.076 \\
(0.061)\end{array}$ & $\begin{array}{l}-0.029 \\
(0.026)\end{array}$ & $\begin{array}{l}-0.000 \\
(0.031)\end{array}$ & $\begin{array}{c}0.025 \\
(0.046)\end{array}$ & $\begin{array}{c}0.008 \\
(0.054)\end{array}$ \\
\hline $\begin{array}{l}\text { State government } \\
\text { ideology (left) }\end{array}$ & $\begin{array}{c}0.054 \\
(0.043)\end{array}$ & $\begin{array}{c}0.126 \\
(0.093)\end{array}$ & $\begin{array}{l}-0.007 \\
(0.038)\end{array}$ & $\begin{array}{l}-0.009 \\
(0.050)\end{array}$ & $\begin{array}{l}0.104 * \\
(0.058)\end{array}$ & $\begin{array}{c}0.066 \\
(0.086)\end{array}$ \\
\hline $\begin{array}{l}\text { Realization of } j \\
(\mathrm{t}-1)\end{array}$ & $\begin{array}{c}0.009 \\
(0.025)\end{array}$ & $\begin{array}{c}0.015 \\
(0.030)\end{array}$ & $\begin{array}{c}0.019 \\
(0.053)\end{array}$ & $\begin{array}{l}-0.018 \\
(0.053)\end{array}$ & $\begin{array}{l}-0.060 * \\
(0.034)\end{array}$ & $\begin{array}{l}-0.025 \\
(0.059)\end{array}$ \\
\hline $\begin{array}{l}\text { Unemployment } \\
\text { rate }(\mathrm{t}-1)\end{array}$ & $\begin{array}{c}0.010 \\
(0.019)\end{array}$ & $\begin{array}{l}-0.009 \\
(0.011)\end{array}$ & $\begin{array}{c}0.009 \\
(0.018)\end{array}$ & $\begin{array}{c}0.021 \\
(0.017)\end{array}$ & $\begin{array}{c}0.006 \\
(0.020)\end{array}$ & $\begin{array}{c}0.023 \\
(0.020)\end{array}$ \\
\hline $\begin{array}{l}\text { Forecast error } \\
(\mathrm{t}-1)\end{array}$ & $\begin{array}{c}0.311^{* * *} \\
(0.048)\end{array}$ & $\begin{array}{l}0.188 * \\
(0.091)\end{array}$ & $\begin{array}{c}0.068 \\
(0.054)\end{array}$ & $\begin{array}{c}0.012 \\
(0.057)\end{array}$ & $\begin{array}{c}0.086 \\
(0.064)\end{array}$ & $\begin{array}{c}0.224 \\
(0.171)\end{array}$ \\
\hline $\begin{array}{l}\text { Year Fixed } \\
\text { Effects }\end{array}$ & Yes & Yes & Yes & Yes & Yes & Yes \\
\hline Observations & 346 & 332 & 351 & 337 & 346 & 332 \\
\hline Groups & 16 & 16 & 16 & 16 & 16 & 16 \\
\hline Within $\mathrm{R}^{2}$ & 0.227 & 0.167 & 0.535 & 0.735 & 0.380 & 0.429 \\
\hline Overall $\mathrm{R}^{2}$ & 0.270 & 0.149 & 0.483 & 0.697 & 0.355 & 0.404 \\
\hline
\end{tabular}

Robust standard errors in parentheses (Huber/White/sandwich standard errors); ${ }^{*} \mathrm{p}<0.10,{ }^{* * *} p<0.01$. 
Table 3

Fixed-effects regressions with standard errors robust to heteroskedasticity (Huber/White/sandwich standard errors) - East German states

\begin{tabular}{|c|c|c|c|c|c|c|}
\hline & $\begin{array}{c}(1) \\
\text { Total } \\
\text { spending } \\
\text { forecast } \\
\text { error, } \\
\text { year t }\end{array}$ & $\begin{array}{c}(2) \\
\text { Total } \\
\text { spending } \\
\text { forecast } \\
\text { error, } \\
\text { year } \mathrm{t}+1\end{array}$ & $\begin{array}{c}\text { (3) } \\
\text { Tax revenue } \\
\text { forecast } \\
\text { error, } \\
\text { year t }\end{array}$ & $\begin{array}{c}(4) \\
\text { Tax revenue } \\
\text { forecast } \\
\text { error, } \\
\text { year } \mathrm{t}+1\end{array}$ & $\begin{array}{c}\text { (5) } \\
\text { Net lending } \\
\text { forecast } \\
\text { error, } \\
\text { year t }\end{array}$ & $\begin{array}{c}\text { (6) } \\
\text { Net lending } \\
\text { forecast } \\
\text { error, } \\
\text { year } \mathrm{t}+1\end{array}$ \\
\hline $\begin{array}{l}\text { Pre-election } \\
\text { forecast }\end{array}$ & $\begin{array}{l}-0.198 * \\
(0.083)\end{array}$ & $\begin{array}{c}-0.552^{* * * *} \\
(0.102)\end{array}$ & $\begin{array}{c}-0.362^{* *} \\
(0.114)\end{array}$ & $\begin{array}{l}-0.251 \\
(0.209)\end{array}$ & $\begin{array}{c}-0.296 * * * \\
(0.059)\end{array}$ & $\begin{array}{l}-0.099 \\
(0.202)\end{array}$ \\
\hline $\begin{array}{l}\text { State government } \\
\text { ideology (left) }\end{array}$ & $\begin{array}{l}0.660 * \\
(0.307)\end{array}$ & $\begin{array}{c}0.686 * * \\
(0.243)\end{array}$ & $\begin{array}{c}0.254^{* *} \\
(0.091)\end{array}$ & $\begin{array}{c}0.077 \\
(0.070)\end{array}$ & $\begin{array}{c}0.244 \\
(0.533)\end{array}$ & $\begin{array}{l}-0.222 \\
(0.390)\end{array}$ \\
\hline $\begin{array}{l}\text { Realization of } j \\
(\mathrm{t}-1)\end{array}$ & $\begin{array}{l}-0.073 \\
(0.171)\end{array}$ & $\begin{array}{c}0.073 \\
(0.071)\end{array}$ & $\begin{array}{l}1.014^{* *} \\
(0.273)\end{array}$ & $\begin{array}{l}-0.489 \\
(0.330)\end{array}$ & $\begin{array}{c}0.071 \\
(0.205)\end{array}$ & $\begin{array}{c}0.503 \\
(0.243)\end{array}$ \\
\hline $\begin{array}{l}\text { Unemployment } \\
\text { rate }(\mathrm{t}-1)\end{array}$ & $\begin{array}{l}-0.097 \\
(0.063)\end{array}$ & $\begin{array}{l}-0.134 \\
(0.063)\end{array}$ & $\begin{array}{c}-0.256 * * \\
(0.061)\end{array}$ & $\begin{array}{c}0.035 \\
(0.064)\end{array}$ & $\begin{array}{l}-0.221 \\
(0.133)\end{array}$ & $\begin{array}{c}-0.264 * * * \\
(0.020)\end{array}$ \\
\hline $\begin{array}{l}\text { Forecast error } \\
(\mathrm{t}-1)\end{array}$ & $\begin{array}{c}0.113 \\
(0.149)\end{array}$ & $\begin{array}{c}0.054 \\
(0.043)\end{array}$ & $\begin{array}{c}0.052 \\
(0.096)\end{array}$ & $\begin{array}{l}-0.078 \\
(0.211)\end{array}$ & $\begin{array}{l}-0.064 \\
(0.224)\end{array}$ & $\begin{array}{l}0.445^{*} \\
(0.209)\end{array}$ \\
\hline $\begin{array}{l}\text { Year Fixed } \\
\text { Effects }\end{array}$ & Yes & Yes & Yes & Yes & Yes & Yes \\
\hline Observations & 64 & 59 & 65 & 60 & 64 & 59 \\
\hline Groups & 5 & 5 & 5 & 5 & 5 & 5 \\
\hline Within $\mathrm{R}^{2}$ & 0.363 & 0.500 & 0.783 & 0.905 & 0.657 & 0.872 \\
\hline Overall $\mathrm{R}^{2}$ & 0.311 & 0.507 & 0.402 & 0.808 & 0.406 & 0.509 \\
\hline
\end{tabular}




\section{Table 4}

Fixed-effects regressions with standard errors robust to heteroskedasticity (Huber/White/sandwich standard errors) - West German states

\begin{tabular}{|c|c|c|c|c|c|c|}
\hline & $\begin{array}{c}\text { (1) } \\
\text { Total } \\
\text { spending } \\
\text { forecast } \\
\text { error, } \\
\text { year t }\end{array}$ & $\begin{array}{c}(2) \\
\text { Total } \\
\text { spending } \\
\text { forecast } \\
\text { error, } \\
\text { year t+1 }\end{array}$ & $\begin{array}{c}\text { (3) } \\
\text { Tax revenue } \\
\text { forecast } \\
\text { error, } \\
\text { year t }\end{array}$ & $\begin{array}{c}\text { (4) } \\
\text { Tax revenue } \\
\text { forecast } \\
\text { error, } \\
\text { year } \mathrm{t}+1\end{array}$ & $\begin{array}{c}(5) \\
\text { Net lending } \\
\text { forecast } \\
\text { error, } \\
\text { year t }\end{array}$ & $\begin{array}{c}(6) \\
\text { Net lending } \\
\text { forecast } \\
\text { error, } \\
\text { year } \mathrm{t}+1\end{array}$ \\
\hline $\begin{array}{l}\text { Pre-election } \\
\text { forecast }\end{array}$ & $\begin{array}{l}-0.052 \\
(0.046)\end{array}$ & $\begin{array}{c}-0.016 \\
(0.034)\end{array}$ & $\begin{array}{l}-0.013 \\
(0.015)\end{array}$ & $\begin{array}{c}0.021 \\
(0.024)\end{array}$ & $\begin{array}{c}0.039 \\
(0.049)\end{array}$ & $\begin{array}{c}0.019 \\
(0.044)\end{array}$ \\
\hline $\begin{array}{l}\text { State government } \\
\text { ideology (left) }\end{array}$ & $\begin{array}{l}-0.009 \\
(0.043)\end{array}$ & $\begin{array}{c}0.098 \\
(0.062)\end{array}$ & $\begin{array}{l}-0.013 \\
(0.038)\end{array}$ & $\begin{array}{l}-0.003 \\
(0.049)\end{array}$ & $\begin{array}{c}0.151 \\
(0.092)\end{array}$ & $\begin{array}{c}0.062 \\
(0.072)\end{array}$ \\
\hline $\begin{array}{l}\text { Realization of } j \\
(\mathrm{t}-1)\end{array}$ & $\begin{array}{c}0.072 * * \\
(0.028)\end{array}$ & $\begin{array}{c}0.178 * * * \\
(0.033)\end{array}$ & $\begin{array}{c}0.041 \\
(0.060)\end{array}$ & $\begin{array}{l}-0.011 \\
(0.071)\end{array}$ & $\begin{array}{c}0.022 \\
(0.034)\end{array}$ & $\begin{array}{l}-0.007 \\
(0.050)\end{array}$ \\
\hline $\begin{array}{l}\text { Unemployment } \\
\text { rate }(\mathrm{t}-1)\end{array}$ & $\begin{array}{c}0.038 \\
(0.024)\end{array}$ & $\begin{array}{l}-0.004 \\
(0.036)\end{array}$ & $\begin{array}{c}0.014 \\
(0.020)\end{array}$ & $\begin{array}{c}0.009 \\
(0.020)\end{array}$ & $\begin{array}{l}-0.022 \\
(0.029)\end{array}$ & $\begin{array}{l}-0.007 \\
(0.027)\end{array}$ \\
\hline $\begin{array}{l}\text { Forecast error } \\
(\mathrm{t}-1)\end{array}$ & $\begin{array}{c}0.261^{* * *} \\
(0.038)\end{array}$ & $\begin{array}{c}0.133 \\
(0.097)\end{array}$ & $\begin{array}{c}0.029 \\
(0.092)\end{array}$ & $\begin{array}{c}0.039 \\
(0.058)\end{array}$ & $\begin{array}{c}0.179 \\
(0.110)\end{array}$ & $\begin{array}{l}-0.071 \\
(0.110)\end{array}$ \\
\hline $\begin{array}{l}\text { Year Fixed } \\
\text { Effects }\end{array}$ & Yes & Yes & Yes & Yes & Yes & Yes \\
\hline Observations & 261 & 253 & 265 & 257 & 261 & 253 \\
\hline Groups & 10 & 10 & 10 & 10 & 10 & 10 \\
\hline Within $\mathrm{R}^{2}$ & 0.255 & 0.315 & 0.539 & 0.721 & 0.355 & 0.493 \\
\hline Overall $\mathrm{R}^{2}$ & 0.126 & 0.0398 & 0.423 & 0.682 & 0.348 & 0.404 \\
\hline
\end{tabular}

Robust standard errors in parentheses (Huber/White/sandwich standard errors); ${ }^{* *} p<0.05$, ${ }^{* * *} p<0.01$. 